\title{
Stable isotope metabolic studies of zinc nutrition in slum-dwelling lactating women in the Amazon valley
}

\author{
BY M. J. JACK SON \\ Department of Medicine, University of Liverpool, P.O. Box 147, Liverpool L69 3BX \\ AND R. GIUGLIANO*, L. G. GIUGLIANO*, E. F. OLIVEIRA \\ AND R. SHRIMPTON \\ Instituto Nacional de Pesquisas da Amazonia, Estrada do Alexio, 1756, CEP 6900 \\ Manaus, Amazonas, Brazil \\ AND I. G. SWAINBANK, \\ British Geological Survey, 64 Gray's Inn Road, London WC1X 8NG
}

(Received 19 February 1987 - Accepted 30 September 1987)

\begin{abstract}
1. Zinc metabolism has been studied in a group of undernourished, slum-dwelling, lactating women in Manaus, Brazil, by means of modified metabolic balance techniques and the stable isotope ${ }^{67} \mathrm{Zn}$.

2. The subjects were found to be consuming a diet which provided an average of $34 \%$ of the recommended dietary allowance for lactating women, but six of the seven appeared to achieve $\mathrm{Zn}$ balance. In five of the subjects use of ${ }^{67} \mathrm{Zn}$ in a stable isotope dilution manner demonstrated that they were absorbing a high proportion of the dietary $\mathrm{Zn}$ (proportional absorption ranged from 0.59 to 0.84 ), suggesting an adaptation to the chronically low intake.

3. Two subjects had marginally low plasma $\mathrm{Zn}$ concentrations, although hair, urine and milk $\mathrm{Zn}$ contents were all within accepted normal values.

4. Preliminary findings on the rate of plasma $\mathrm{Zn}$ turnover and the size of the exchangeable body $\mathrm{Zn}$ pool obtained using ${ }^{67} \mathrm{Zn}$ suggest that these subjects may have a reduction in both.
\end{abstract}

Acute $\mathrm{Zn}$ deficiency in man is a well-recognized and characterized problem which is known to occur in a variety of different circumstances (Moynahan, 1974; Kay et al. 1976; Weismann et al. 1978). $\mathrm{Zn}$ deficiency may also occur as a complicating factor in protein-energy malnutrition (Golden \& Golden, 1981) and has been proposed to be present in some poor urban communities (Prasad et al. 1961, 1963). Shrimpton $(1980,1984)$ and Amorosa \& Shrimpton (1984) have studied nutritional intakes in the poor urban population of Manaus in the Amazon region of Brazil and found that several nutrients were quantitatively deficient compared with internationally recommended intakes; these were $\mathrm{Zn}$, vitamin $\mathrm{A}$, calcium, thiamin and riboflavin. Furthermore, $\mathrm{Zn}$ was found to be the most limiting nutrient when compared with international standards (Shrimpton, 1984). This survey work, together with the finding that $35 \%$ of this population, in the lowest socio-economic group, have low serum $\mathrm{Zn}$ concentrations, has led to the suggestion that this urban population may be Zn-deficient (Shrimpton, 1980; Shrimpton et al. 1983, 1985). The (US) National Academy of Sciences/National Research Council (1980) recommend a daily intake of $15 \mathrm{mg} \mathrm{Zn}$ for adults, increasing by $5 \mathrm{mg}$ in pregnant women and by $10 \mathrm{mg}$ during lactation, but it appears that the daily intake of people in the low socio-economic group in Manaus may be as low as $6 \mathrm{mg}$ (Shrimpton, 1980). It is unknown if these subjects have the ability to maintain $\mathrm{Zn}$ balance on such a low dietary intake and how the homeostatic mechanisms of the body respond to this intake.

\footnotetext{
* Present address: Department of Nutrition, University of Brasilia, Caixa Posta, 15-3035, CEP 70919 Brasilia DF, Brazil.
} 
Stable-isotope techniques are now available which allow the study of whole-body $\mathrm{Zn}$ metabolism in normal human subjects (Janghorbani \& Young, 1980; Janghorbani et al. 1981; Turnlund et al. 1982; Jackson et al. 1984), but these techniques have primarily been used to assess $\mathrm{Zn}$ absorption rates and other aspects of $\mathrm{Zn}$ metabolism in subjects maintained in specialist metabolic facilities and consuming relatively artificial diets. We have attempted to use these techniques to obtain information on $\mathrm{Zn}$ metabolism in chronically undernourished subjects in Manaus, living in their own surroundings and consuming their normal diet. These studies have examined $\mathrm{Zn}$ balance and the rates of $\mathrm{Zn}$ absorption and gastrointestinal secretion in a small group of poor lactating women while consuming their normal dietary intake. In addition preliminary findings relating to the rates of $\mathrm{Zn}$ turnover in these subjects have been obtained from the stable isotope studies.

\section{METHODS}

Seven lactating mothers were studied in detail. All mothers were feeding infants under 3 months of age. The breast-milk intake of the infants was supplemented with a cassava (Manihot esculenta) pap and some bottled formula milk. The mothers were visited by a nutritionist and by the authors several times each day for ten consecutive days during which time information concerning the socio-economic conditions of the family and dietary intake of the mother was obtained.

\section{Zn balance studies}

Subjects undertook a modified conventional metabolic balance study at home in which dietary intake of $\mathrm{Zn}$ was calculated and the $\mathrm{Zn}$ content of all output was measured by atomic absorption spectrometry.

\section{Dietary intake}

All subjects were provided with utensils of standard and known size in order to quantify intake. Each recorded the quantity of food eaten at every meal and the dietary intake was calculated each day by a nutritionist using $24 \mathrm{~h}$ recall techniques. The major foods consumed were cassava flour, white bread and fish. The intake each day was found to be very similar since the diet varied little, consisting mainly of these three ingredients. Nutrient composition of the diet was then calculated from tables of Amazonian foods previously produced by Rebelo \& Shrimpton (1984). Drinking-water samples were taken each day and analysed for $\mathrm{Zn}$ content.

\section{Faecal output}

The $10 \mathrm{~d}$ of study were divided into two $5 \mathrm{~d}$ balance periods. Subjects were given $500 \mathrm{mg}$ carmine markers at the beginning of the study and at 5 and $10 \mathrm{~d}$ later. All faecal specimens passed from the beginning of the study until the appearance of the last marker were collected in polyethylene-lined $\mathrm{Zn}$-free containers. The carmine markers were used to decide which stool specimens derived from each dietary period. Stools from each subject for each period were then pooled, homogenized, and analysed for $\mathrm{Zn}$ by atomic absorption spectrometry as previously described (Jackson, 1977).

\section{Urinary Zn output}

Sequential $24 \mathrm{~h}$ urine specimens were collected into polyethylene-lined containers for the $10 \mathrm{~d}$ of the study. The volumes of these were measured, and portions were taken and frozen at $-20^{\circ}$ until analysed for $\mathrm{Zn}$ by atomic absorption spectrometry. 


\section{Milk Zn output}

Regular breast-milk samples from the subjects were collected during the $10 \mathrm{~d}$ of the study. The $\mathrm{Zn}$ content of these was not found to vary with the time of day at which the sample was provided or whether it was taken pre- or post-feed. The volume of milk supplied was calculated by weighing the baby before and after milk feeds. Weighing of babies was undertaken by trained personnel on balances accurate to $\pm 0.5 \mathrm{~g}$. This gave a range of values for volume of milk per feed from each subject. It was assumed that the maximum volume was delivered at each feed and total possible milk output was calculated from this volume and the number of times nursed. The subjects were instructed to feed their infants on either breast milk or other foods at individual feeds and not to mix feeds. The maximum possible amount of $\mathrm{Zn}$ excreted via this route was used for all calculations.

\section{Stable isotope studies}

${ }^{67} \mathrm{Zn}$ was used in an isotope dilution manner as previously described (Jackson et al. 1984). Each subject received a single intravenous injection of $4 \mathrm{mg} 93.11 \%$ enriched ${ }^{67} \mathrm{Zn}$ in sterile saline $(9 \mathrm{~g}$ sodium chloride/ 1$)$, and $2 \mathrm{~h}$ later received the first carmine faecal marker at which time urine and faecal collections were commenced. Blood $(10 \mathrm{ml})$ was taken for ${ }^{67} \mathrm{Zn}$ analysis and further blood samples were taken at 3,6 and $9 \mathrm{~d}$. Analyses of ${ }^{67} \mathrm{Zn}$ enrichment of plasma and pooled faecal samples were undertaken by thermal ionization mass spectrometry as previously described (Jackson et al. 1984). A logarithmic plot of the plasma enrichment of ${ }^{67} \mathrm{Zn} v$. time after the $\mathrm{Zn}$ infusion was plotted and from this the plasma enrichment at the mid-point of each balance period was derived. Comparison of this value with the ${ }^{67} \mathrm{Zn}$ enrichment of the pooled faeces from that period allowed the proportion of the total faecal $\mathrm{Zn}$ derived from gastrointestinal secretion to be calculated. Since the total faecal output $(F)$ is equal to the dietary intake $(D)$ minus the $\mathrm{Zn}$ absorbed $(A)$ plus that secreted into the gut $(S)$ (i.e. $F=D-A+S$ ) a knowledge of the gastrointestinal $\mathrm{Zn}$ secretion, the total faecal $\mathrm{Zn}$ and the dietary intake allowed the $\mathrm{Zn}$ absorbed to be calculated (i.e. $A=D-F+S$ ) (Jackson et al. 1984; Evans et al. 1979; Weigand \& Kirchgessner, 1978).

\section{Assessment of $Z$ in status}

Plasma and hair $\mathrm{Zn}$ contents were analysed at the beginning of the study using atomic absorption spectrometry. These studies were approved by the human studies ethical committee of the University of Amazonas, Brazil, and all subjects gave their informed consent.

\section{RESULTS}

The socio-economic status of the subjects together with their average intake of energy, protein and $\mathrm{Zn}$ at the time of the study is given in Table 1. All subjects were consuming less than the World Health Organization's (1973) recommendations for energy, but had adequate protein intake. $\mathrm{Zn}$ intake, as expected, was well below the (US) National Academy of Sciences/National Research Council (1980) recommendations. Financial income was extremely low and in two families no monetary income was declared.

\section{Zn status}

The plasma and hair $\mathrm{Zn}$ content is shown in Table 2 together with control values obtained in the UK using the same analytical techniques. On this basis two subjects had marginally low plasma $\mathrm{Zn}$ concentrations, but all had normal hair $\mathrm{Zn}$ content. 
Table 1. Socio-economic status and nutritional intakes of the slum-dwelling lactating Amazonian women

\begin{tabular}{|c|c|c|c|c|c|c|}
\hline Subject & $\begin{array}{c}\text { Age } \\
\text { (years) }\end{array}$ & $\begin{array}{c}\text { No. in } \\
\text { household }\end{array}$ & $\begin{array}{c}\text { Family } \\
\text { income } \\
\text { (USS/month) }\end{array}$ & $\begin{array}{c}\text { Energy intake } \\
(\% \text { of recom- } \\
\text { mended intake*) }\end{array}$ & $\begin{array}{c}\text { Protein intake } \\
(\% \text { of recom- } \\
\text { mended intake*) }\end{array}$ & $\begin{array}{l}\text { Zinc intake } \\
\quad(\mathrm{mg} / \mathrm{d})\end{array}$ \\
\hline A & 18 & 7 & $8 \cdot 3$ & $65 \cdot 2$ & $176 \cdot 1$ & $9 \cdot 1$ \\
\hline B & 25 & 9 & $9 \cdot 7$ & 47.0 & 136.9 & $7 \cdot 2$ \\
\hline $\mathrm{C}$ & 18 & 9 & $18 \cdot 8$ & $71 \cdot 3$ & 167.4 & $7 \cdot 3$ \\
\hline D & 29 & 5 & $14 \cdot 1$ & $75 \cdot 5$ & $175 \cdot 2$ & $9 \cdot 6$ \\
\hline $\mathbf{E}$ & 24 & 5 & - & $80 \cdot 0$ & $207 \cdot 1$ & $11 \cdot 1$ \\
\hline $\mathrm{F}$ & 22 & 8 & - & $43 \cdot 5$ & $87 \cdot 5$ & $5 \cdot 8$ \\
\hline$G$ & 20 & 4 & $37 \cdot 7$ & $71 \cdot 2$ & 195.6 & $8 \cdot 6$ \\
\hline Mean & - & - & $17 \cdot 7$ & $64 \cdot 8$ & $163 \cdot 7$ & $8 \cdot 4$ \\
\hline
\end{tabular}

* Recommended daily intakes are taken from World Health Organization (1973) and were: energy $11500 \mathrm{~kJ}$ $(2750 \mathrm{kcal})$, protein $46 \mathrm{~g}$.

Table 2. Plasma and hair zinc content of seven slum-dwelling lactating Amazonian women

\begin{tabular}{ccc} 
Subject & $\begin{array}{c}\text { Plasma } \begin{array}{c}\text { Zn concentration } \\
(\mathrm{mg} / \mathrm{l})\end{array} \\
\text { H }\end{array}$ & $\begin{array}{c}\text { Hair Zn content } \\
(\mu \mathrm{g} / \mathrm{g})\end{array}$ \\
$\mathrm{B}$ & $1 \cdot 04$ & 157 \\
$\mathrm{C}$ & $0 \cdot 73$ & 209 \\
$\mathrm{D}$ & $0 \cdot 91$ & 111 \\
$\mathrm{E}$ & $0 \cdot 86$ & 124 \\
$\mathrm{~F}$ & 0.86 & 242 \\
$\mathrm{G}$ & 0.69 & 921 \\
& $1 \cdot 01$ & 124 \\
Normal values* & $0 \cdot 75-1 \cdot 15$ & $72-248$ \\
\hline
\end{tabular}

* Derived from studies on normal subjects in England using the same methodology.

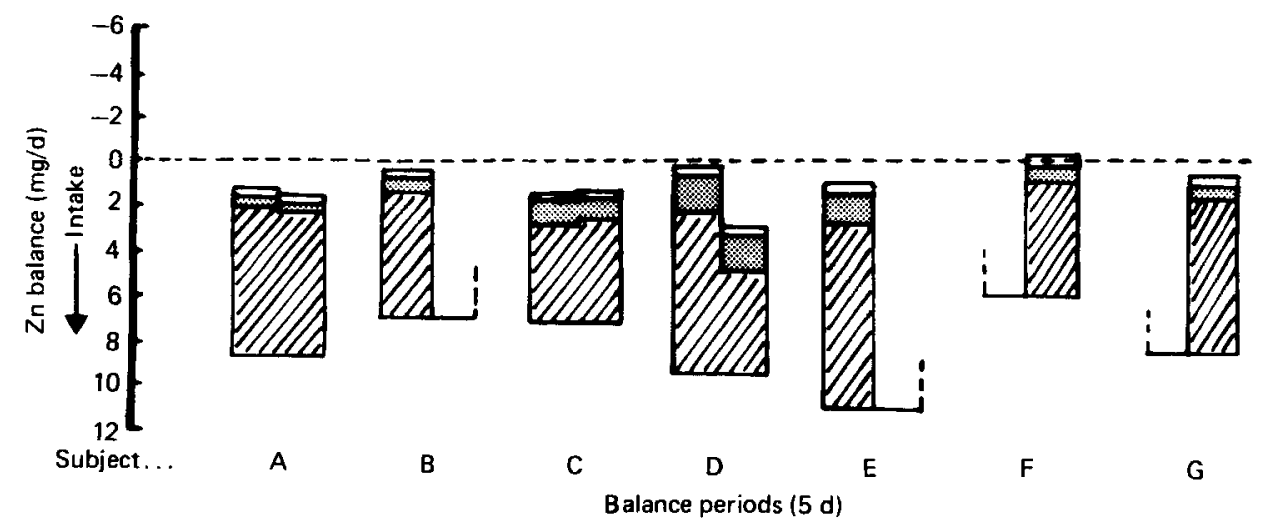

Fig. 1. Results of metabolic balances for zinc in subjects A-G (for details of subjects, see Table 1). When plotting balance results, dietary intake is plotted downward from the zero horizontal line. From this baseline, output of faecal (滛), milk (圆) and urinary ( $\square$ ) $\mathrm{Zn}$ is plotted above. If cumulative output is above the zero line then the subject is in negative balance: if output falls below the zero line, the balance is positive. All subjects were studied for two consecutive $5 \mathrm{~d}$ periods; where one period of balance is shown, incomplete loss of faecal material had occurred. 


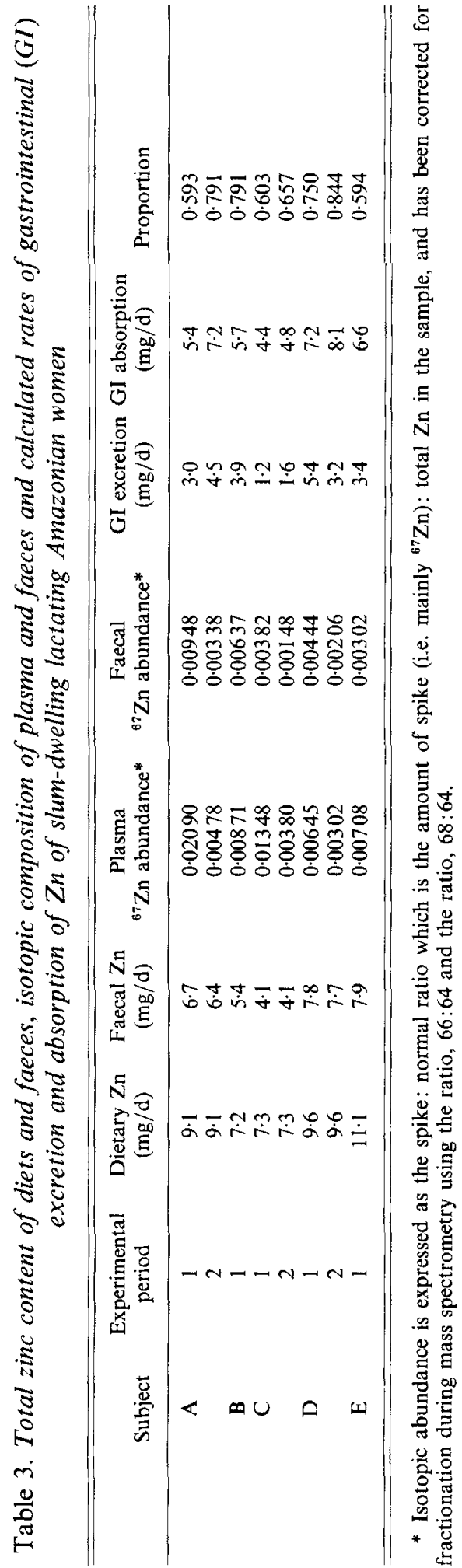


Table 4. Plasma ${ }^{6} \mathrm{Zn}$ turnover, exchangeable $\mathrm{Zn}$ pool size and whole-body $\mathrm{Zn}$ turnover in five slum-dwelling lactating Amazonian women

\begin{tabular}{cccc}
\hline Subject & $\begin{array}{c}\text { Plasma Zn } \\
\text { turnover, } \\
t_{\frac{1}{2}}(\mathrm{~d})\end{array}$ & $\begin{array}{c}\text { Exchangeable } \\
\text { Zn pool } \\
(\mathrm{mg})\end{array}$ & $\begin{array}{c}\text { Whole body } \\
\text { turnover*, } \\
t_{\frac{1}{2}} \text { (d) }\end{array}$ \\
\hline A & $2 \cdot 2$ & 86 & 39 \\
B & $2 \cdot 5$ & 235 & 77 \\
C & $2 \cdot 8$ & 159 & 105 \\
D & $4 \cdot 4$ & 418 & 96 \\
E & $2 \cdot 9$ & 324 & 107 \\
Mean & $2 \cdot 8$ & 244 & 85 \\
\hline
\end{tabular}

$t_{2}^{1}$, Half-life.

* Whole-body $\mathrm{Zn}$ turnover (i.e. the apparent $t_{1}$ of the exchangeable $\mathrm{Zn}$ pool) was calculated from the exchangeable $\mathrm{Zn}$ pool size and the rate of $\mathrm{Zn}$ excretion during the first $5 \mathrm{~d}$ balance period.

\section{Zn balance}

The $\mathrm{Zn}$ balance results from the seven subjects studied are presented in Fig. 1. These results are presented in the manner previously described (Jackson, 1977). Complete dietary intake values were obtained in all seven subjects, as were urine and breast-milk collections. The mean $24 \mathrm{~h}$ urinary $\mathrm{Zn}$ for each $5 \mathrm{~d}$ period and the maximum possible excretion of $\mathrm{Zn}$ in the breast milk were used in all calculations. The completeness of faecal collections was difficult to ascertain in the present study. The frequent presence of the investigators in the homes of the subjects ensured the constant reitteration of the need for complete collections, but even so incomplete faecal collections were obtained on four occasions. In the remaining periods the faecal $\mathrm{Zn}$ output was found to be a relatively constant proportion of the dietary $\mathrm{Zn}$ intake with a mean of $72 \%$ (range $56-81 \%$ ). If substantial and random variations in the completeness of these collections had occurred this would not have been expected.

Full balance values were therefore obtained in a total of ten of fourteen possible $5 \mathrm{~d}$ periods. In eight of the ten complete periods a positive balance result was obtained and in one, zero balance was found. The remaining balance gave a slightly negative result.

\section{Rate of gastrointestinal secretion and absorption of $\mathrm{Zn}$}

${ }^{67} \mathrm{Zn}$ values were obtained in five subjects (A, B, C, D and $\left.\mathrm{E}\right)$. In other subjects ${ }^{67} \mathrm{Zn}$ values could not be analysed because of technical problems. Table 3 shows the enrichment of the plasma ${ }^{67} \mathrm{Zn}$ at the mid-point of each period together with the enrichment of the pooled faecal samples for that period. The enrichment of the plasma with ${ }^{67} \mathrm{Zn}$ at the mid-point of each period was obtained by plotting the ratio, ${ }^{67} \mathrm{Zn}$ spike: normal $(\mathrm{S}: \mathrm{N})$ on a logarithmic scale $v$. time-interval following injection (Jackson et al. 1984). The 'best fit' straight line was drawn through these points and from this the enrichment at $2.5 \mathrm{~d}$ and at $7.5 \mathrm{~d}$ was derived. Gastrointestinal secretion and absorption of $\mathrm{Zn}$ were then calculated as previously described (Jackson et al. 1984) and are also shown in Table 3, together with the dietary and faecal $\mathrm{Zn}$ levels and the rates of gastrointestinal absorption expressed as a proportion of the dietary intake. The proportion of $\mathrm{Zn}$ absorbed in these subjects was generally high, ranging from 0.593 to 0.844 . 


\section{Turnover rates of body $\mathrm{Zn}$ and body pools of exchangeable $\mathrm{Zn}$}

The half life of the plasma ${ }^{67} \mathrm{Zn}$ in the five subjects was derived from the plot $\log S: \mathrm{N} v$. time-interval after injection and is shown in Table 4 . This ranged between 2.25 and $4.4 \mathrm{~d}$. Extrapolation of the plasma ${ }^{67} \mathrm{Zn}$ enrichment back to the time of injection allowed an approximation of the size of the pool of $\mathrm{Zn}$ with which the ${ }^{67} \mathrm{Zn}$ had exchanged to be calculated. This is shown in Table 4 and ranges from 86 to $418 \mathrm{mg} \mathrm{Zn}$. Whole-body $\mathrm{Zn}$ turnover (i.e. the apparent half life of the exchangeable pool) was also calculated from the exchangeable $\mathrm{Zn}$ pool size and the total rate of $\mathrm{Zn}$ excretion (i.e. the sum of the rates of gastrointestinal, milk and urinary $\mathrm{Zn}$ excretions) during the first $5 \mathrm{~d}$ balance period (Jackson et al. 1984). This gave a range of values between 39 and $107 \mathrm{~d}$ (Table 4).

\section{DISCUSSION}

Acute severe $\mathrm{Zn}$ deficiency is now a well-recognized and characterized problem which is known to occur in a variety of different circumstances (Moynahan, 1974; Kay et al. 1976; Weismann et al. 1978), but the effects of chronically low dietary intakes of $\mathrm{Zn}$ are much less well documented and indeed the minimum dietary intake of $\mathrm{Zn}$ which is sufficient for body requirements is unknown. The (US) National Academy of Sciences/National Research Council (1980) recommend a dietary intake of $15 \mathrm{mg}$ for adults increasing to $20 \mathrm{mg}$ for pregnant women, and $25 \mathrm{mg}$ for lactating women. Several studies have suggested that many population groups do not achieve this, even in relatively affluent developed countries (e.g. Lyon et al. 1979). Overt $\mathrm{Zn}$ deficiency may occur as a complicating factor in acute protein-energy malnutrition (Golden \& Golden, 1981) but the consequence of chronic long-term marginal $\mathrm{Zn}$ intakes on the ability of the body to maintain $\mathrm{Zn}$ balance has not been extensively studied.

We have attempted to study $\mathrm{Zn}$ metabolism in poor lactating women while they continued to consume their normal daily diet. The subjects studied were of poor socioeconomic status with their normal dietary intake only providing an average $62.4 \%$ of the recommended energy intake (Table 1 ).

The daily dietary $\mathrm{Zn}$ intake of the subjects ranged from 5.8 to $11.1 \mathrm{mg}$, with a mean of $8.4 \mathrm{mg}$ or $33.6 \%$ of the recommended dietary allowance for lactating women. Nevertheless, in eight of the ten balance periods for which full sets of values were obtained, a positive balance was calculated and the mean balance for the seven subjects (Fig. 1) was $1.3 \mathrm{mg}$ positive. The findings therefore suggest that lactating women consuming much less than the recommended dietary allowance have the ability to maintain $\mathrm{Zn}$ balance. Excretion of $\mathrm{Zn}$ in sweat was not measured in these studies. There is some disagreement concerning the likely losses of $\mathrm{Zn}$ in sweat. Prasad et al. (1963) reported that losses of $\mathrm{Zn}$ in sweat are of the order of $1.1 \mathrm{mg} / 1$, while Jacob et al. (1981) felt that surface losses of $\mathrm{Zn}$ were much less important, only increasing the apparent dietary requirements by $5 \%$. The large losses of $\mathrm{Zn}$ in the sweat were found in studies where sweat was collected and analysed but, in everyday life, evaporation of water is likely to deposit $\mathrm{Zn}$ salts on the skin. Absorption of $\mathrm{Zn}$ via the skin has been demonstrated (Hallmans \& Lasek, 1985) and it is therefore unknown what is the extent of the net loss via this route in normal circumstances. We therefore feel that our results provide good evidence of the ability of these lactating women to at least achieve $\mathrm{Zn}$ balance on their normal diet.

In animal experiments it has been found that the homeostatic mechanisms regulating body $\mathrm{Zn}$ have a considerable capacity to adapt in order to compensate for decreased dietary intake. Rats fed on a diet of low- $\mathrm{Zn}$ content increase the proportion of $\mathrm{Zn}$ absorbed such 
that greater than 0.90 of a test dose of Zn may be absorbed (Becker \& Hoskstra, 1971; Jackson et al. 1981) and variation in the gastrointestinal excretion of the element also occurs in an attempt to maintain normal tissue levels. Similar mechanisms appear to exist in man; Jackson et al. (1984) have demonstrated changes in the rates of both absorption and gastrointestinal excretion of $\mathrm{Zn}$ with variations in $\mathrm{Zn}$ intake, while others have demonstrated that the proportion of a tracer dose of $\mathrm{Zn}$ absorbed increased during acute dietary Zn depletion studies in normal subjects (Istfan et al. 1983). We have utilized the isotope dilution technique to examine both the rate of gastrointestinal absorption and excretion of $\mathrm{Zn}$ while the subjects consumed their normal diet. This has revealed a proportional absorption of $\mathrm{Zn}$ between 0.593 and $0.844 \%$ of the dietary intake (Table 3). Solomons (1982) reviewed reports from several laboratories where proportional absorption of $\mathrm{Zn}$ had been measured using isotopic techniques and concluded that when $\mathrm{Zn}$ was given orally in an aqueous solution the mean absorption of tracer ranged from 0.43 to 0.69 whereas when the isotope was consumed in the presence of assorted beverages, food or meals, proportional absorption ranged from $0 \cdot 14$ to 0.41 . The findings obtained in the present study therefore suggest that the lactating Brazilian women were absorbing a higher proportion of the ingested $\mathrm{Zn}$ from their entire diet than is usually the case for tracer doses of $\mathrm{Zn}$ given with foodstuffs. The rates of gastrointestinal excretion of $\mathrm{Zn}$ in the subjects studied here range from 1.2 to $5.4 \mathrm{mg} / \mathrm{d}$. The lower values obtained (Table 3 ) are similar to the obligatory endogenous losses in faeces and urine found by Baer \& King (1984) in a study of acute experimental $\mathrm{Zn}$ depletion in young men and by Hess et al. (1977) in young women. It therefore appears that in the subjects studied here both the rates of gastrointestinal absorption and gastrointestinal $\mathrm{Zn}$ excretion are adapted to the chronicallylow $\mathrm{Zn}$ intake by absorption of a high proportion from the diet and by reduction of the losses of $\mathrm{Zn}$ into the gut. This demonstration of a relatively high fractional rate of gastrointestinal absorption of $\mathrm{Zn}$ also indicates that the availability of $\mathrm{Zn}$ in this particular diet must be relatively high. This is somewhat surprising, but the cassava flour and white bread consumed in Manaus contain little fibre or phytate since the white bread is highly refined and the cassava flour is fermented. The diet is also high in fish protein, a combination of factors which favour $\mathrm{Zn}$ availability.

The kinetics of $\mathrm{Zn}$ turnover between different body pools is extremely complex and it has recently been calculated that there are at least fourteen 'pools' or compartments contributing to the kinetics of plasma $\mathrm{Zn}$ turnover (Wastney et al. 1986). Analysis of the kinetics of human $\mathrm{Zn}$ with this degree of refinement are unlikely to be possible given the sensitivity of current stable isotope techniques. In addition the frequency of blood sampling and the length of study required are not likely to be possible under 'field' conditions such as those in the present study. However, we have utilized the plasma ${ }^{67} \mathrm{Zn}$ enrichment data from the present study to obtain preliminary data on $\mathrm{Zn}$ turnover in these subjects. An examination of the activity of radioactive $\mathrm{Zn}$ in plasma following intravenous injection in normal subjects obtained by Wastney et al. (1986) and other workers (Aamodt et al. 1979; Foster et al. 1979; Prasad et al. 1963) reveals that the disappearance curve of isotopic plasma $\mathrm{Zn}$ could be resolved into a series of phases, the rapid parts of which were completed in a matter of hours. In the present study the initial plasma samples were not taken until $2 \mathrm{~h}$ after injection of the isotope in order to allow this equilibration and dilution of the isotope with endogenous $\mathrm{Zn}$ to have occurred.

In studies over a similar time-course to those described here Jackson et al. (1984) found that the half-life of plasma ${ }^{67} \mathrm{Zn}$ turnover in one normal subject was $12.5 \mathrm{~d}$. In addition, Prasad et al. (1963) also found that in phase IV of their studies ( $10 \mathrm{~h}$ to $10 \mathrm{~d}$ postintravenous ${ }^{65} \mathrm{Zn}$ injection), the half life of the plasma $\mathrm{Zn}$ was 4.9-5.9 d. It therefore appears that the lactating Amazonian women studied here may have a more rapid turnover of plasma $\mathrm{Zn}$ (mean half-life $2 \cdot 8 \mathrm{~d}$ ) than expected. 
The increased plasma $\mathrm{Zn}$ turnover found in the subjects may also have introduced a slight negative bias in the calculations of gastrointestinal $\mathrm{Zn}$ secretion and hence in the absorption rates. In these calculations the overall faecal ${ }^{67} \mathrm{Zn}$ enrichment is compared with the plasma enrichment at the mid-point of each period, the periods being timed from ingestion of the carmine marker. However, there is a time lag between the marker entering the mouth until it passes into the part of the gastrointestinal tract where the bulk of $\mathrm{Zn}$ secretion occurs. Our subjects were generally found to have gut transit times of about $24 \mathrm{~h}$ and since animal data suggests that gastrointestinal $\mathrm{Zn}$ secretion occurs in the small intestine it is likely that the time-lag between the marker entering the mouth and the area of $\mathrm{Zn}$ secretion is relatively short $(<6 \mathrm{~h})$. In a normal subject, such as that previously described (Jackson et al. 1984) in whom the half-life of the plasma $\mathrm{Zn}$ was $12.5 \mathrm{~d}$, this lag would have little effect on the value for ${ }^{67} \mathrm{Zn}$ enrichment used in the calculations, but in the subjects described here with increased plasma $\mathrm{Zn}$ turnover rates the effect is more marked. For example, the calculated plasma $\mathrm{Zn}$ half-life for subject $\mathrm{A}$ was $2 \cdot 2 \mathrm{~d}$ and if it is assumed that the true value of plasma ${ }^{67} \mathrm{Zn}$ enrichment which should be used in calculations was that $6 \mathrm{~h}$ after the mid-point, then this would mean the calculated gastrointestinal secretion rate was underestimated by about $10 \%$ resulting in an underestimate of the proportional absorptional rate by about $0 \cdot 035$. This argument is not taken further because of a lack of knowledge of the actual sites of $\mathrm{Zn}$ secretion into the gut, but it should be noted that the values for gastrointestinal secretion and absorption rates and proportional absorption quoted in Table 3 may be slight underestimates.

The exchangeable pool with which the ${ }^{67} \mathrm{Zn}$ rapidly equilibrated in these subjects was found to be variable with a mean of $244 \mathrm{mg}$, which is well below the $650 \mathrm{mg}$ found in the study of one normal male subject by Jackson et al. (1984). No other comparable values for this measurement appear to have been presented. Total body turnover of $\mathrm{Zn}$ (i.e. the half life of the exchangeable $\mathrm{Zn}$ pool) was found to be very variable in the lactating women studied, the average half-time was $85 \mathrm{~d}$ which is of the same order as the estimates made by Jackson et al. (1984) and Aamodt et al. (1979) in studies of comparable duration in normal subjects (i.e. $138 \mathrm{~d}$ and $87 \mathrm{~d}$ respectively).

The values obtained for both exchangeable pool size and whole-body $\mathrm{Zn}$ turnover were very variable. This variation did not appear to correlate with height, weight, $\mathrm{Zn}$ intake or $\mathrm{Zn}$ status of the subjects. While this may indicate that the simplified model of $\mathrm{Zn}$ kinetics used here is inapplicable in the subjects studied, it is also true that equivalent levels of variability were found in the rates of gastrointestinal $\mathrm{Zn}$ excretion (Table 3) and that variations of up to $250 \%$ were found in more-commonly measured variables such as the hair $\mathrm{Zn}$ content (Table 2). Large variability between subjects may therefore be a feature of $\mathrm{Zn}$ metabolism in this population. It can therefore be argued that, although inconclusive, these results suggest that in the subjects studied here a chronically low dietary Zn intake may have reduced the average size of the exchangeable $\mathrm{Zn}$ pool in the body and increased the rate of plasma $\mathrm{Zn}$ turnover without affecting the average rate of whole-body turnover of $\mathrm{Zn}$.

The question remains as to whether these subjects consuming a relatively-low dietary intake of $\mathrm{Zn}$ were in fact $\mathrm{Zn}$-deficient. In this situation conventional indicators of body $\mathrm{Zn}$ status provide ambiguous results. The subjects studied showed similar levels of plasma $\mathrm{Zn}$ to the larger group examined by Shrimpton (1980), in that two of the seven had plasma $\mathrm{Zn}$ concentrations less than our accepted lower limit of normal $(0.75 \mathrm{mg} / 1)$. However, the validity of a marginally low plasma $\mathrm{Zn}$ in the diagnosis of $\mathrm{Zn}$ deficiency has been the subject of considerable discussion since decreased plasma $\mathrm{Zn}$ concentrations can occur in various circumstances unassociated with $\mathrm{Zn}$ deficiency (Solomons, 1979). Hair $\mathrm{Zn}$ levels were normal in all subjects, but the use of this index of $\mathrm{Zn}$ status has also been questioned (Solomons, 1979; Hambidge, 1982; Dores \& Paine, 1985). Urine $\mathrm{Zn}$ levels were within our 
accepted normal range $(100-500 \mu \mathrm{g} / 24 \mathrm{~h})$ and the breast milk of the subjects contained a relatively normal concentration of $\mathrm{Zn}$ when compared with other population groups (Vuori \& Kuitunen, 1979; Dorea et al. 1985). However, Shrimpton et al. (1983, 1985) provided evidence of a relative lack of $\mathrm{Zn}$ in these subjects by undertaking a supplementation study in other lactating women from the same population. They found that $\mathrm{Zn}$ supplements prevented a significant decrease in breast milk $\mathrm{Zn}$ content from 30 to $120 \mathrm{~d}$ of lactation, maintained the milk retinol content at a higher level throughout lactation and reduced the incidence of diarrhoea in the offspring. In addition, the results presented here suggest that the lactating women may have a low exchangeable pool of $\mathrm{Zn}$ and a rapid turnover of plasma Zn.

Taken together, these studies suggest that a chronically low $\mathrm{Zn}$ intake may lead to a suboptimal state of $\mathrm{Zn}$ nutrition which conventional indicators of $\mathrm{Zn}$ deficiency (i.e. plasma, urine or hair $\mathrm{Zn}$ levels) may not reliably detect and in which the subjects are in $\mathrm{Zn}$ balance with homeostatic mechanisms maximally adapted to conserve $\mathrm{Zn}$. However, supplementation studies suggest that this apparent 'status quo' may not be without 'cost' to the subject in terms of other biological functions. If indeed such a state does exist in various chronically undernourished populations then, of the commonly used techniques for assessing $\mathrm{Zn}$ status, only a trial of $\mathrm{Zn}$ supplements while monitoring a specific indicator of nutritional status (i.e. growth rates in children or milk quality in lactating women), or perhaps detailed and time-consuming measurements of the exchangeable $\mathrm{Zn}$ pool sizes and plasma turnover rate will reliably detect the situation.

The authors would like to acknowledge financial support from the British Council, the Brazilian Council for Scientific and Technological Development (CNPQ) and the Nestlé Nutrition Research Grant Programme. Helpful discussions and encouragement from Professor J. C. Waterlow and Professor R.H.T. Edwards are also gratefully acknowledged. The contribution of I.G.S. is published with the approval of the Director of The British Geological Survey (NERC).

\section{REFERENCES}

Aamodt, R. L., Rumble, W. F., Johnsson, G. S., Foster, D. \& Henkin, R. I. (1979). American Journal of Clinical Nutrition 32, 559-569.

Amorosa, M. C. M. \& Shrimpton, R. (1984). Ecology, Food and Nutrition 14, 307-323.

Baer, M. T. \& King, J. C. (1984). American Journal of Clinical Nutrition 39, $556-570$.

Becker, W. M. \& Hoekstra, W. G. (1971). In The Intestinal Absorption of Metal Ions, Trace Elements and Radionucleotides, pp. 229-256 [S. C. Skoryna and D. Waldron-Edwards, editors]. Oxford: Pergammon Press.

Dorea, J. G., Homer, M. R. \& Campanate, M. L. (1985). Acta Paediatrica Scandinavica 74, 891-896.

Dores, J. C. \& Paine, P. A. (1985). Human Nutrition: Clinical Nutrition 39, 389-398.

Evans, G. W., Johnson, E. C. \& Johnson, P. E. (1979). Journal of Nutrition 109, 1258-1264.

Foster, D. M., Aamodt, R. L., Henkin, R. I. \& Berman, M. (1979). American Journal of Physiology 237, R340-R349.

Golden, M. H. N. \& Golden, B. E. (1981). British Medical Bulletin 37, 31-36.

Hallmans, G. \& Lasek, J. (1985). Scandinavian Journal of Plastic and Reconstructive Surgery 19, 119-125.

Hambidge, K. M. (1982). American Journal of Clinical Nutrition 36, 943-949.

Hess, F. M., King, J. C. \& Margen, S. (1977). Journal of Nutrition 107, 1610-1620.

Istfan, N. W., Janghorbani, M. \& Young, V. R. (1983). American Journal of Clinical Nutrition 38, $187-194$.

Jackson, M. J. (1977). Journal of Clinical Pathology 30, 284-287.

Jackson, M. J., Jones, D. A. \& Edwards, R. H. T. (1981). British Journal of Nutrition 46, 15-27.

Jackson, M. J., Jones, D. A., Edwards, R. H. T., Swainbank, I. G. \& Coleman, M. L. (1984). British Journal of Nutrition 51, 199-208.

Jacob, R. A., Sandstead, H. H., Munoz, J. M., Klevay, L. M. \& Milne, D. B. (1981). American Journal of Clinical Nutrition 34, 1379-1383.

Janghorbani, M., Ting, B. T. G., Istfan, N. W. \& Young, V. R. (1981). American Journal of Clinical Nutrition 34, $581-591$. 
Janghorbani, M. \& Young, V. R. (1980). American Joumal of Clinical Nutrition 33, 2021-2030.

Kay, R. G., Tasman-Jones, C., Pybus, J., Whiting, R. \& Black, H. (1976). Annals of Surgery 183, 331-340.

Lyon, T. D. B., Smith, H. \& Smith, L. B. (1979). British Journal of Nutrition 42, 413-417.

Moynahan, E. J. (1974). Lancet ii, 399-400.

National Academy of Sciences/National Research Council (1980). Recommended Dietary Allowances, 9th ed. Washington DC: National Academy of Sciences.

Prasad, A. S., Halsted, J. A. \& Nadami, M. (1961). American Journal of Medicine 31, 532-546.

Prasad, A. S., Miale, A., Farid, Z., Sandstead, H. H. \& Schulert, A. R. (1963). Journal of Laboratory \& Clinical Medicine 61, 537-549.

Rebelo, Y. R. \& Shrimpton, R. (1984). Ciencia e Tecnologia de Alimentos 4, 68-78.

Shrimpton, R. (1980). Studies of zinc nutrition in the Amazon valley. PhD Thesis, University of London.

Shrimpton, R. (1984). Archivos Latinamericanos de Nutricion 349, 615-629.

Shrimpton, R., Alencar, F. H., Vasconcelos, J. C. \& Rocha, Y. R. (1985). Nutrition Research Suppl. 1, 338-342.

Shrimpton, R., Marinho, H. A., Rocha, Y. R. \& Alencar, F. H. (1983). Proceedings of the Nutrition Society 42, $122 \mathrm{~A}$.

Solomons, N. W. (1979). American Journal of Clinical Nutrition 32, 856-871.

Solomons, N. W. (1982). American Journal of Clinical Nutrition 35, 1048-1075.

Turnlund, J. R., Michel, M. C., Keyes, W. R., King, J. C. \& Margen, S. (1982). American Journal of Clinical Nutrition 35, 1033-1040.

Vuori, E. \& Kuitunen, P. (1979). Acta Paediatrica Scandinavica 68, 33-37.

Wastney, M. E., Aamodt, R. L., Rumble, W. F. \& Henkin, R. I. (1986). American Journal of Physiology 251, R398-R408.

Weigand, E. \& Kirchgessner, M. (1978). Nutrition and Metabolism 22, 101-112.

Weissmann, K., Wadskov, S., Mikkelsen, H. J., Knudsen, L., Christensen, K. C. \& Storgaard, L. (1978). Archives of Dermatology 114, 1509-1511.

World Health Organization (1973). Energy and Protein Requirements, Technical Report Series. no. 522. Geneva : WHO. 